\title{
Remix and Reproduction in the Post-Internet Age: A Contemporary Art + Design Pedagogy
}

\author{
LIAT BERDUGO \\ Assistant Professor, University of San Francisco
}

\begin{abstract}
Having taught many university-level studio art courses, I have noticed in my students a surprising investment in the notion of originality and authorship in their own creative practices, even as they freely participated in the exchange, reuse, and remixing of visual languages on social media and the internet. This paper focuses on techniques to incorporate remix practices into studio art and design classrooms, arguing that students benefit significantly from a focus on what I term "remix pedagogy," meaning a method and practice of teaching that brings together both the concepts and the creative use of remix tactics.

I argue that remix pedagogy offers four key benefits to visual arts pedagogy. First, it productively reconfigures outmoded notions of originality and authenticity, freeing students from the highpressure myth of the artist as a lone genius. In doing so, remix pedagogy offers a second benefit: it introduces students to new modes of making that promote ideation, design thinking, and creative production, including the support of collaborative frameworks in artistic processes. Thirdly_and crucially - these new modes of making teach visual art students how to use artistic practice as social commentary with a cultural fluidity previously unavailable to them. Finally, remix pedagogy familiarizes art and design students with the principles of fair use, promoting complex critical reasoning by forcing them to reason through what makes a work "transformative" and to distinguish fair use from plagiarism. This paper provides examples from my own teaching in Copy Culture, a course I developed at the University of San Francisco.
\end{abstract}

\section{INTRODUCTION}

"Everything in and of the Internet is a stimulus package for the endlessly derivative, in the same way that a mirror image is a derivative of an original. Not a copy, but a mirror."

- Metahaven $^{1}$

After years of teaching within the Design Program at the University of San Francisco, I began to notice a dichotomy in how students approached notions of originality inside studio courses versus 
outside them. In studio critiques, students often asked each other, "Is that an original asset?" meaning, "Did you draw, animate, or code that piece of creative work yourself?" Students were highly invested in locating the source of authorship of visual materials and valued self-authorship above all else. However, outside of critique, students were moving freely and swiftly in the postmodernist, post-author culture of the remix: downloading, circulating, mashing up, memeifying, and then recirculating existing visual pieces of cultural material without any regard for originality, most notably on social media. Online, students were participating in what some scholars have called the "endless hybridization process" of visual materials, meaning that they engaged in a remix culture that not only expects but plans that any resultant work might also be remixed by others. $^{2}$

We know, of course, that remixes are not limited to occasional forays on social media for visual artists. $^{3}$ Twentieth-century art has been filled with a rich history of collage works, derivative work, and détournements: from Futurism to Cubism, from Dada to Situationism, and from pop art to new media art. While historically the term "remix" stems from the field of music - namely, from the audio-editing techniques and DJ practices of simultaneously playing, scratching, and overlapping records together to create new sounds-remixing visual culture has a deep history as a means by which designers and artists explicitly reference, engage, and critique antecedent sources in their own language, the language of visual culture. ${ }^{4}$ Yet my students loathed to embrace remix culture in their own creative practices.

This paper argues that the disciplines of art and design have much to gain from introducing students to what I call "remix pedagogy," meaning a method and practice of teaching both the concepts and the creative use of remix tactics in artistic production. Drawing from my studio-seminar hybrid course, Copy Culture: Design, Remix, and Reproduction in the Post-Internet Age, ${ }^{5}$ housed within the Design Program in the Department of Art + Architecture at the University of San Francisco, I argue that the mobilization of remix practices serves art and design students in four broad ways. First, remix practices demystify the visual creation processes by reconfiguring archaic, patriarchal notions of the artist as a "lone genius," and the unhelpful notions of originality and authenticity that accompany it. Second, remix practices offer new modes of creation to art and design students that promote creative production, ideation, and design thinking - including the support of collaborative frameworks as students learn how to "riff" off of each other's projects and processes. Third, remix pedagogy in art and design teaches students how to use artistic practice as social commentary with a cultural fluidity previously unavailable to them. Fourth and finally, a thorough familiarization with fair use doctrines serves students' art and design careers and helps them think critically as they reason through what makes a work "transformative" and learn to distinguish fair use from plagiarism. Ultimately, when equipped with knowledge of fair use and reasoning, I argue that students' fears of violating copyright diminish greatly, and they are able to actively engage in the production and reproduction of culture in their own artistic practices. 
My work on this topic follows existing scholarship on the ways in which remix practices have been embraced pedagogically by other disciplines in the humanities, such as Gender, Sexuality, and Feminism; ${ }^{6}$ History; ${ }^{7}$ Politics and Civic Engagement; ${ }^{8}$ English Language Learning; ${ }^{9}$ and Communication. ${ }^{10}$ In Computer Science, students often learn to program though re-working open source code and creating newly executable programs from the results. Such remix practices are so highly normalized that the literature rarely dubs it "remix pedagogy." The artistic disciplines of music, ${ }^{11}$ creative writing, ${ }^{12}$ video production, ${ }^{13}$ and new media ${ }^{14}$ have likewise embraced remix tactics in creative production. This embrace is felt not only in higher education, but also in secondary schools, where teachers have introduced remix theory and practice in classrooms to engage students as active constructors of meaning, rather than as passive digesters of prescribed history and content, and have employed remix pedagogy to upend the authority structures of the traditional classroom to promote student engagement. ${ }^{15}$

Remix pedagogy is especially valuable now, when the mainstreaming of remix culture - meaning what Diakopoulous et al. describe as "a society that encourages derivative works by combining or modifying existing media" - has made it far more visible than it was a decade ago. ${ }^{16}$ Indeed as Eduardo Navas, Owen Gallagher, and xtine burrough argue in the introduction to their book, The Routledge Companion to Remix Studies, the production of creative works via remix tactics has become a necessarily political activity entailing a friction between "creative freedom, intellectual property and copyright law." 17 For art practitioners, this friction is often a generative space of creative production. But what is it for the art student? This paper addresses how a pedagogical focus on remix culture benefits art and design students in their creative work in higher educational contexts, and offers my own course as a sample framework for productively destabilizing archaic notions of authorship, creativity, collaboration, and ownership in artistic practices.

\section{DEMYSTIFYING THE CREATIVE PROCESS: RECONFIGURING NOTIONS OF ORIGINALITY AND AUTHENTICITY}

Notions of originality and authorship have long-standing lineages within studio art: the Neapolitan creation ideal is embodied by a solitary genius, working alone in his bare studio (the genius is always a "him"), and working without an ounce of external influence. This genius generates copious quantities of innovative artwork sourced from the brilliant, uninhibited originality of his mind. In my courses in the Design program at the University of San Francisco, I qualitatively observed that my own students - steeped in this history-were stuck on its conventional notions of artistic creation.

Of course, we know that "art is sourced," as Jonathan Lethem has written in his 2007 article, "The Ecstasy of Influence," a piece the author self-described as a "plagiarism," as it was itself composed as a collage of uncited sources. ${ }^{18}$ Lethem "writes" that those who make art are "apprentices graz[ing] in the field of culture," meaning that artists meander within a space that is not empty or blank, but filled with the artworks and cultural productions of others, which they consume and digest in order to produce their own. ${ }^{19}$ 
Therefore the role of successful remix pedagogy must begin by demystifying the creation processes itself. In other words, remix pedagogy must begin by reconfiguring notions of originality and authenticity. For students to freely graze in the "fields of culture," they must first be unshackled from the restraining ideals of sole authorship and originality.

In the course Copy Culture, I address the issue of sole authorship first by qualitatively assessing student ideas surrounding artistic ideation and copying. All students submit anonymous written responses to the following two questions (among others) on the first day of the course - questions which I myself have sourced from artist Nick Briz: ${ }^{20}$

Q1. As a designer or artist, where do your ideas come from?

Q2. As a designer artist, do you ever copy others?

This first question, "As an artist, where do your ideas come from?" aims to locate, site, contextualize, and situate ideation. To explain where their ideas come from, all but two of my students referenced other people as their influences - artists, designers, or simply "other individuals I hang out with." These responses far outnumbered any other type of source (although students did regularly reference their environment, experiences, and the internet/media as well). Student responses made straightforward references to the work of others, such as, "I get most of my inspiration from Pinterest—-seeing other people's work." Others responded that their ideas come from the aspirational influence of "other artworks that I see and other creators who I want to be like."

Student responses seemed to acknowledge that "art is sourced," meaning that they are influenced by others around them, and that the locus of their creative ideation lies in others. Their sentiments hearkened back to that of Kenneth Koch, poet, who proclaimed: "I'm a writer who likes to be influenced." ${ }^{21}$

However, when I asked students in the next survey question, "As a designer or artist, do you ever copy others?," only one student replied with what I have characterized as an "embrace" of this influence of others. This student's wholehearted embrace was also paired with a trend I call attribution, which I saw in many more student replies:

Yeah! I've taken concepts from poets and re-interpreted them in my own poetry. I've made found-footage films. I made a short film where I basically took Vines and gifs and stuff from the internet and archived them within my own framework in order to talk about Weird Internet and celebrate creativity. I think especially in experimental film and video work the idea of copying and reappropriating media is really interesting. I always make sure to credit the original artist too, and even ask them for permission when possible! I think that's an important component when I'm basically, like, straight-up stealing videos and stuff from other artists. But I'm totally for this as a concept. 
A few students responded more philosophically, stating that there is nothing original and everything has been "done," therefore "of course" they copy the work of others:

I think it's so hard to not copy others when it comes to art because I think that everything has like already [sic] been done so how do you try to do something that doesn't exist yet?

This student's sentiment offers a complaint that originality is hard to find in art and design. Embedded within this complaint is a sentiment that originality is valuable, and that creating works that are tissues of citations, mashups of visualities, and remixes of culturally known visuals is not inherently valuable as a mode of artistic production.

All other students replied that they attempt to make the work "their own" if they copy others, that they copy for educational purposes only, that they never copy work in public art they produce, or that they likely copy others without realizing it. Responses of this sort read more like the following:

When I do copy others, I do it in my personal time for personal practice ONLY. I never use another artist's design or ideas in my own work. I find inspiration in other people's art and use that inspiration to create work of my own.

This student copies art and design in order to learn, a model akin to the artistic apprenticeships that began in the Renaissance. This student admits to sourcing inspiration from others, but then declares that the work is her "own." At what point a work becomes one's own (what I call the "it's-mine" conundrum), rather than a complex and interwoven fabric of inspirations, remains a thing to unpack.

Copy Culture's pedagogical goal in asking these two questions together ("As an artist, where do your ideas come from?" and "As an artist, do you ever copy others?") was twofold. The first goal was to meet students at their own ideation points-a well-known idea called competency-based education, or "meeting students where they are" with assessment, modular lessons, and responsive facilitation. ${ }^{22}$ The second goal was to cause ideological friction for students at the point of the "it'smine" conundrum. This friction causes students to ask the question at the heart of authorship and authenticity for remix pedagogy: how can a creator of a piece of art acknowledge their influences, yet claim sole authorship?

In Copy Culture, I also chose to address the issue of sole authorship through seminar-style scholarship with students. Students read and responded to essays such as Malcolm Gladwell's "Creation Myth," which addresses the myth of sole innovation by way of technological examples; ${ }^{23}$ Richard Brilliant's "Roman Copies: Degrees of Authenticity," which contextualizes notions of copies and originality in art history by addressing how Roman copies of Greek statues were considered not merely references to the originals, but works of art to be appreciated and admired in and of themselves ${ }^{24}$ Roland Barthes's "The Death of the Author," which addresses the birth of 
the modernist and sole author figure, and then philosophically "kills" the modernist author figure in favor of a postmodern view which gives primacy to the reader, ${ }^{25}$ Michel Foucault's "What is an Author?," a further postmodernist view on authorship, ${ }^{26}$ and Jonathan Lethem's "The Ecstasy of Influence," which addresses the radically generative possibilities of embracing influence in creative practice more broadly. ${ }^{27}$ Together, these texts serve to disabuse art and design students of the notion that authorship and creatorship can be located within an original being, show them that notions of originality are culturally and historically constructed, and open them up to embracing remix tactics for creative production.

Simultaneously, students studied the work of artists who mobilize appropriative tactics creatively, in order to build up an understanding of the potential for remix tactics in creative processes. Artists drew from the fields of creative writing, photography, painting, video, performance, culture jamming, and new media. ${ }^{28}$ Each student selected one artist from a list to research extensively and present to their classmates in the form of a 10-minute, Pecha Kucha-style talk. ${ }^{29}$ Pedagogically, it was important that each student choose an artist of their own volition (rather than being assigned one by me) to increase their level of investment in and satisfaction with their research process. Students became the "class experts" on their own selected artist, and facilitated a class discussion after their presentation with three prepared questions pertaining to topics of appropriation, remix, and reuse in artistic practice. These conversations allowed for nuanced, project-specific dialogue about remixes. For instance, the student who presented on Richard Prince asked her classmates:

Some people love Prince's Cowboy photographs but hate his New Portraits series because they think it's okay to appropriate a large corporation but not okay to "take" from an individual. Do you agree or disagree, and why?

This student prompted her fellow classmates to think through questions of artistic motivation, as well as harm, in appropriative practices. In doing so, she led us to a more nuanced stance towards appropriative tactics: it is not that all artistic appropriation is good, or all is bad, but instead context, motivation, and message of an artwork all direct our opinions of artistic value. These conversations furthered students' thinking about how they would appropriate remix tactics in their own works of art and design.

\section{NEW MODES OF ARTISTIC CREATION AND COLLABORATION}

"Start copying what you love. Copying, copying, copying. And at the end of the copy, you will find yourself."

- Yohji Yamamoto ${ }^{30}$

Drawing from a strong conceptual basis in the theory and practice of remix, students began working with remix practices in their own work. Such practices offer new modes of creation to art and design students and promote creative production, ideation, and design thinking, including the support of collaborative work frameworks for remixing each other's artistic processes. 
In their first assignment, students created a series of five prints using xerography art, or photocopy art, all based on the same "original" source material. Students were encouraged to engage with tactics such as

- Creating a "double/multiple exposure," i.e., running the same paper through the copier multiple times to superimpose multiple images on the same page

- Incorporating photocopied images into collages or multimedia artworks

- Moving an object on the platen (glass bed) during the copy process, as in the above images, to create a distorted picture

- Adjusting the settings of the copier, e.g., the color balance and contrast, to change the look of an image

- Copying a copy (or a copy of a copy of a copy) of an image

Students were told that a successful series would consider the whole series as a sum of its parts, with each print both standing on its own and complementing the works in the series, and moreover that careful attention must be paid to composition, detail, and especially to the conceptual work of appropriation as it relates to originality and authorship.

Resulting work exceeded expectations, notably on the level of experimentation. Students reported feeling free to experiment with this project in ways that had previously seemed impossible. This "freedom" is precisely the liberation caused by deconstructing ideals of sole authorship and replacing such ideals with the notion that creation derives from a collaboration between an artist and source material. It is likewise a "freedom" derived from embracing experimental forms of visual production, and allowing chance and errors to contribute to the creative process. Many students took the assignment as an opportunity to remix well-known visual items, such as the packaging of Wonder Bread (figures 1 and 2) or the logo of MUNI, San Francisco's public transit agency (figures 3 and 4). On their own, these students discovered that one of the key communicative potentials of a remix is its ability to reference existing source material for a viewer and to mobilize such a reference as a kind of "artistic citation" to be referenced, inverted, and manipulated in search of new meaning. 


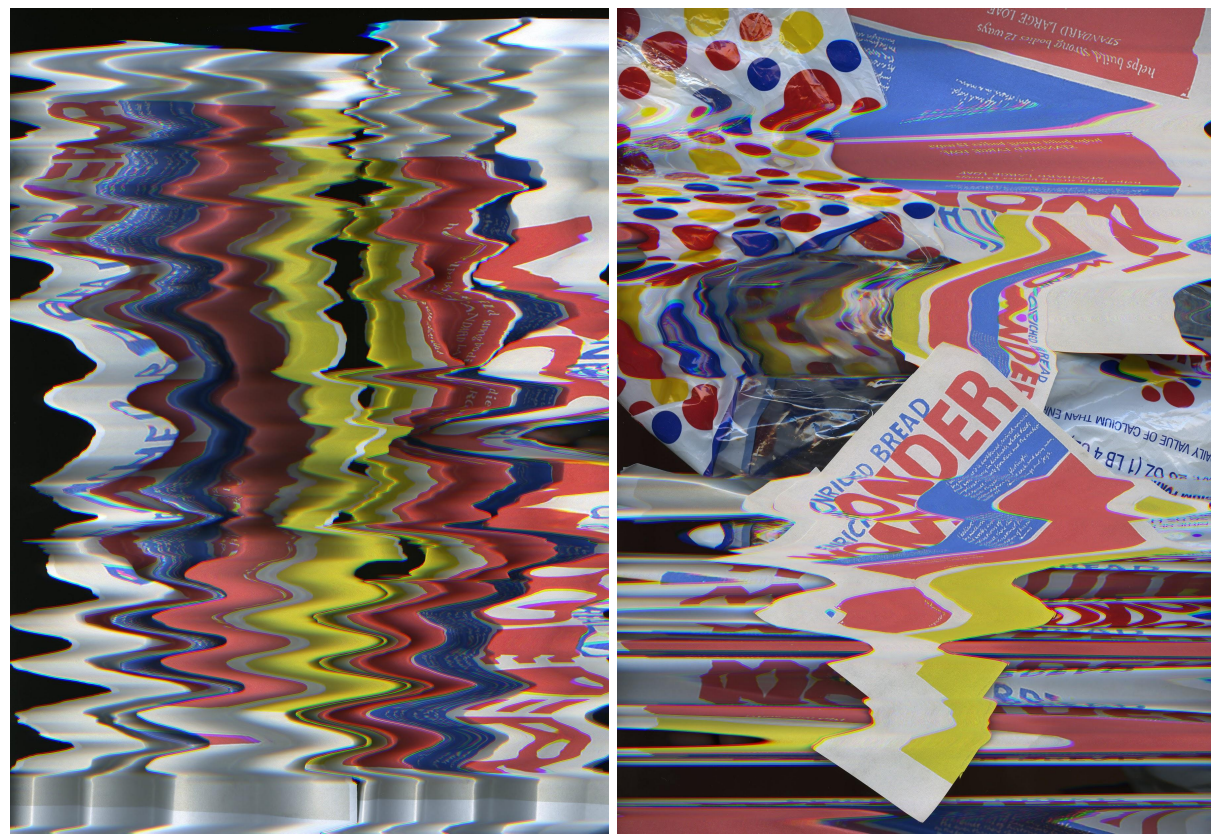

Figures 1 and 2. Two digital inkjet prints produced by student Rachel Handler in Copy Culture (2017) using tactics of xerography, or photocopy art. This student was inspired by the canonical forms, shapes, and colors of the Wonderbread's logo and packaging design.
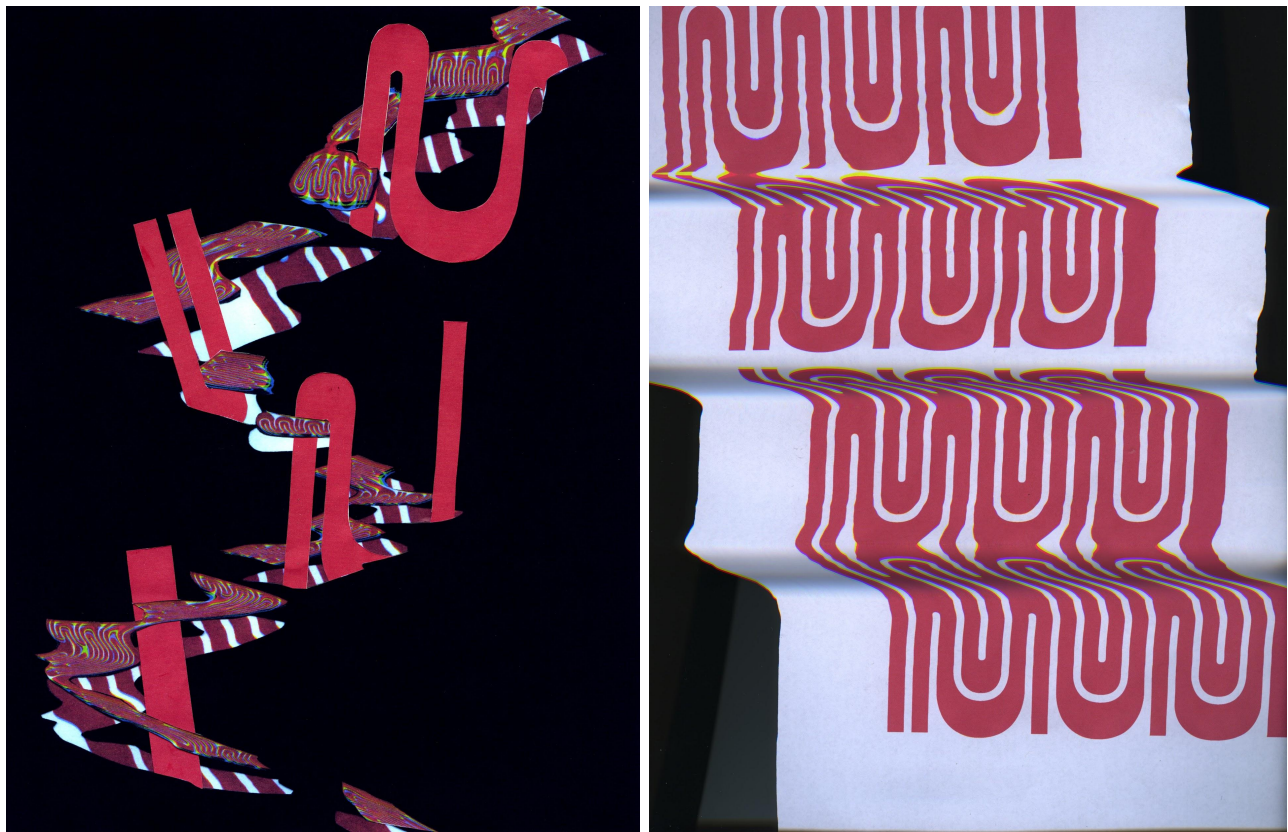
Figures 3 and 4. Two digital inkjet prints produced by student Sheila Burke in Copy Culture (2019) using tactics of xerography, or photocopy art. This student was inspired by the wavy lines in the logo of MUNI, San Francisco's Municipal Transit Agency.

Student work in this simple assignment also exceeded expectations in terms of consideration of dimensionality and space. Prior to this course, students had received extensive training on exclusively two-dimensional design in both print and digital contexts. However, when faced with the task of creating a copy of a copy of a copy, students began to experiment outside of their disciplinary training. One student, for instance, began incorporating sculptural and threedimensional aspects into his prints by curling, scanning, and re-photocopying his prior work (figure 5). Another student took the assignment as an opportunity to explore scale, by using appropriative tactics to zoom in on and blur visual elements in the production of nine prints at a massive scale at which he had not yet worked (figure 6). Forced to experiment by the constraints of the assignment, these students remixed original works in ways that pushed them outside their previous disciplinary and artistic boundaries.

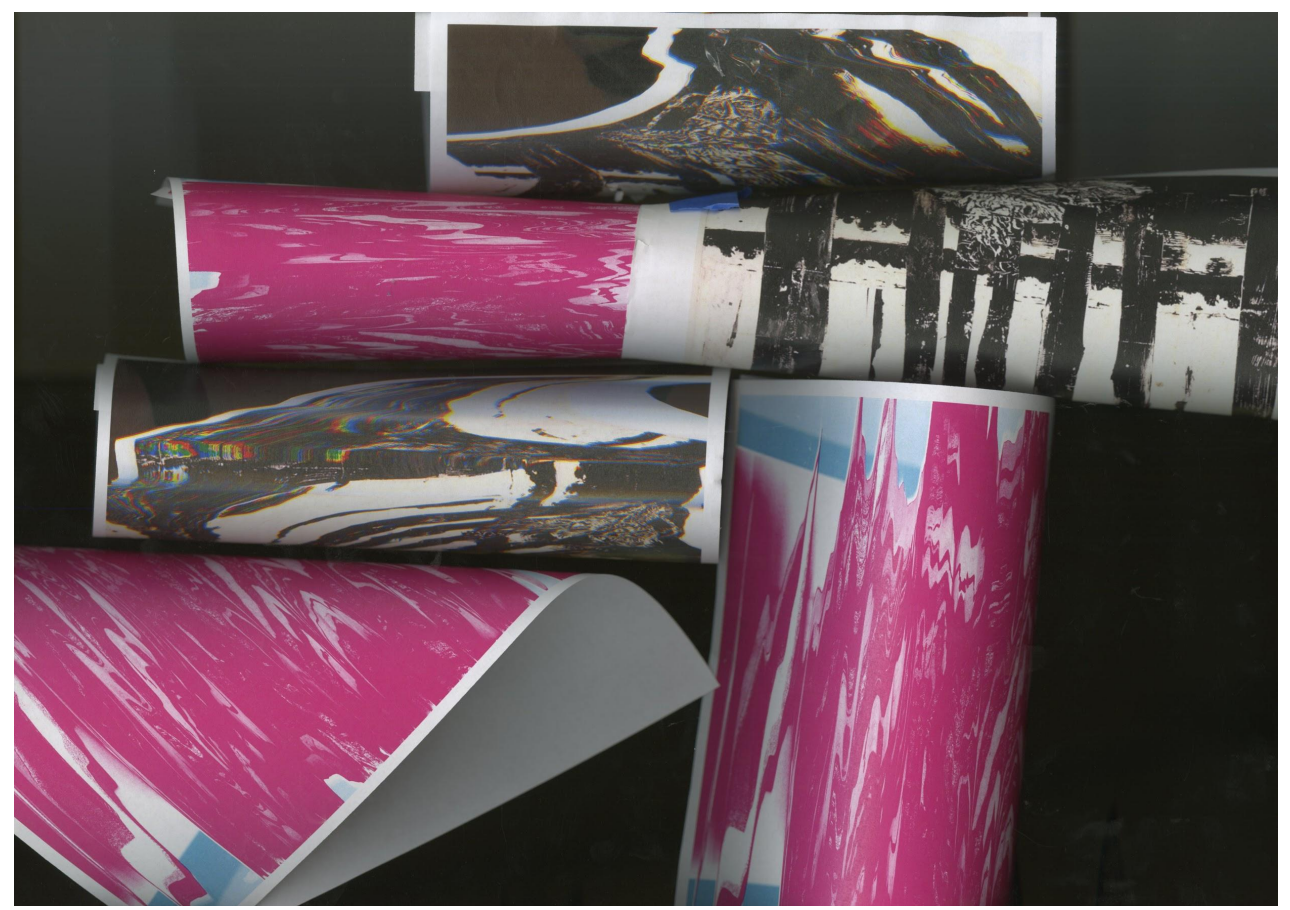

Figure 5. A sculptural digital inkjet print produced by student Chris Sayas in Copy Culture (2017) using tactics of xerography, or photocopy art. While this student was trained only in two-dimensional design practices, the assignment to remix an original prompted him to incorporate considerations of a third or sculptural dimension into his artistic practice. 


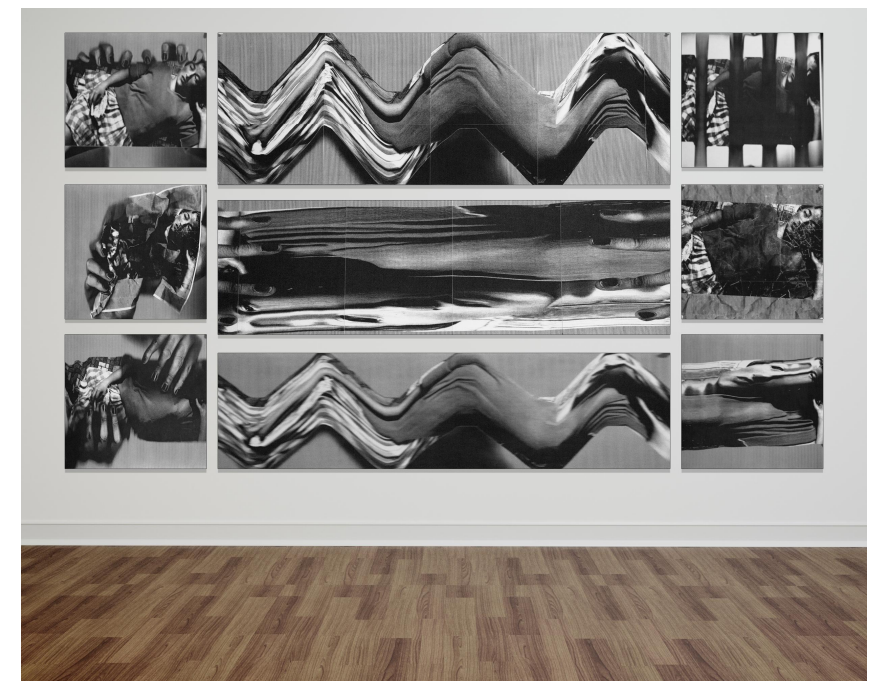

Figure 6. A set of nine digital inkjet prints produced by student Terence Ho in Copy Culture (2017) using tactics of xerography, or photocopy art, and incorporating questions of scale.

As part of this assignment, students also began learning how to remix each other's projects and creative processes in what became a new framework for collaborative work. Each student swapped one xerography print with another student, and then made a new visual mashup of their own work and the work of their classmate. Through this process, students learned to recreate others' techniques, explore new compositions, and work with source material that was personal in nature. In the resultant prints, students found that collaboration in remixing yielded visual and textural variance unavailable to them previously (figures 7 and 8 ).
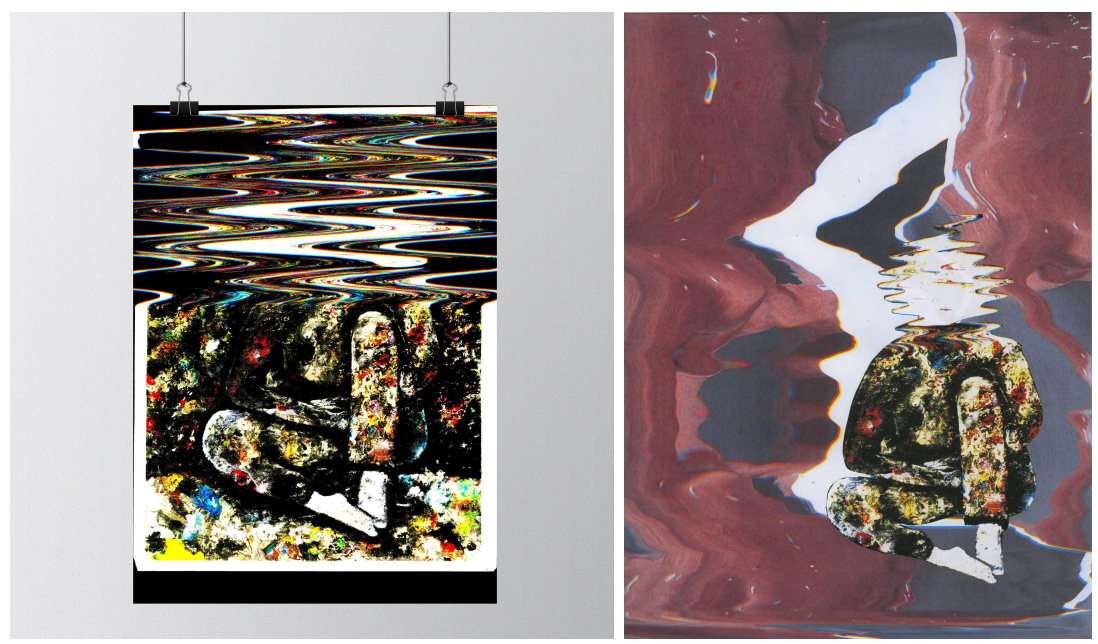

Figures 7 and 8. A digital inkjet print produced by one student Grace Domecus (left), which was then remixed into the work of student Teddy Ziolkowski (right) in Copy Culture, 2017. By remixing his own work with that of his fellow classmate, Ziolkowski was able to find visual and textural variance. 
As a culmination of the unit on xerography, Copy Culture partnered with local curatorial duo FICTILIS to install a show of xerography pieces in the USF Art + Architecture student gallery. The show, titled 10.-22.-38 Astoria after the the first image/phrase ever produced using the technology known as photocopying, had a dual purpose: to further question notions of originality and authorship, and to invite the public to participate in collaborative remix practices. ${ }^{31}$

The exhibition was a functional photocopy shop in the gallery, in which viewers were invited to take down anything off the walls and make copies or remixes of them (figures 8, 9, and 10). The copies could then be taken home and collected as art objects, or returned to the gallery walls thereby creating an ever-changing exhibition of prints. However, the making of copies was not free; instead, it followed a unique pricing structure developed by FICTILIS:

- Free copy of anything you bring in with you

- $\$ 1$ for one copy of anything on the walls

- $\$ 5$ for one original on the walls, if you replace it with a copy

- $\$ 10$ for one original on the walls, without making a copy

The point of the pricing structure was to further challenge notions of originality by monetizing societal value over notions of the "original." Of course, if a viewer paid $\$ 5$ for an "original" on the walls and replaced it with a copy, who was to say that the "original" had not previously been someone else's copy? And, was a viewer willing to pay $\$ 10$ for a work on the walls simply to take it out of circulation? By introducing the financialization of originality into the gallery, 10.-22.-38 Astoria's pricing structure forced questions of originality and value into the exhibition space. At the same time, the exhibition dismantled the conception that a gallery show's contents must be stable, inert, and untouchable to viewers, transforming the gallery from what Lawrence Lessig would call a space of "read-only" culture where art is passively consumed, to one of "read/write" culture in which producers and consumers can engage in reciprocal acts of creation. ${ }^{32}$

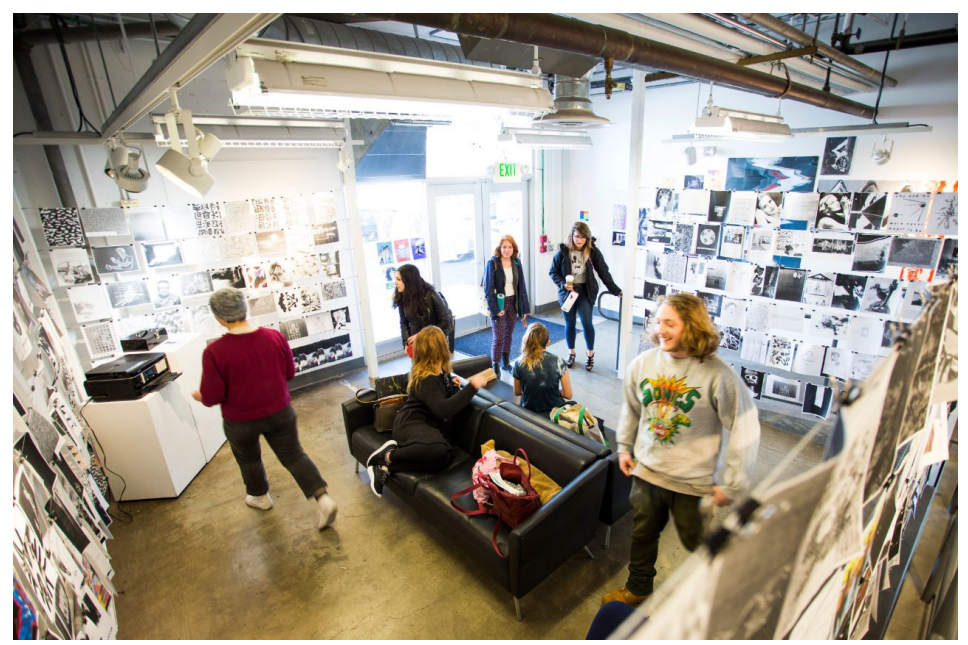




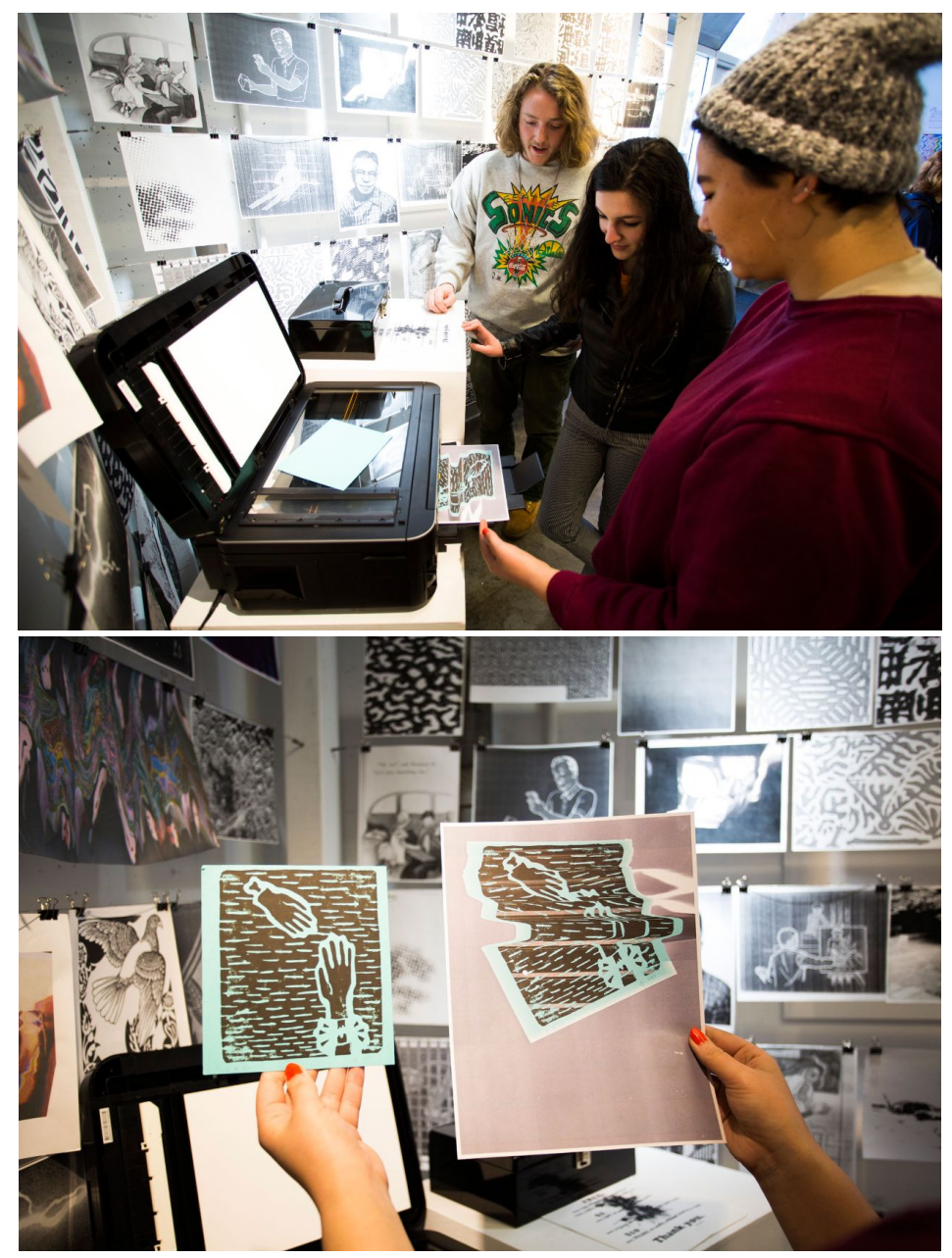

Figures 9, 10, and 11. The exhibition 10.-22.-38 Astoria, presented in partnership with FICTILIS, installed in the Department of Art + Architecture student gallery at the University of San Francisco in 2017.

\section{REMIXES IN ART AND DESIGN OFFER SOCIAL COMMENTARY}

A third way that the mobilization of remix practices serves art and design students concerns the message of their works: I argue that remix pedagogy teaches visual art students how to use artistic practice as social commentary with a cultural fluidity previously unavailable to them. Through studio assignments, students in Copy Culture used remix tactics to critique large social issues, most notably questions of social oppression and destructive capitalist determinism embodied in technological platforms. The ways students did so is best seen through examples of their work. 
For the second studio project in Copy Culture, students were asked to focus on appropriative practices whose explicit goal was to make a statement on their sources. Students read Guy Debord, "A User's Guide to Détournement," in which Debord writes of his theory of détournement:

Any elements, no matter where they are taken from, can be used to make new combinations....The mutual interference of two worlds of feeling, or the juxtaposition of two independent expressions, supersedes the original elements and produces a synthetic organization of greater efficacy. Anything can be used. ${ }^{33}$

I took students on a field trip to the Prelinger Library, which is an independent, appropriationfriendly library in San Francisco with a high volume of materials in the public domain. There, students selected one book to "détourn" from the collection. Students researched the origins of their selected book, including its surrounding books, its publisher, its contents, and its material and formal qualities as an object. Each student then authored, created, printed, and bound a new publication that remixed their archival source material and repurposed the book's contents using the mutual conductive techniques of détournement, culture jamming, and tactical media introduced in class.

One student chose to détourn a 1950s text about the danger of atomic bombs into a social commentary on the prevalence of on-demand food delivery service in the technological sharing economy sector. The student transformed the original text, Atomic Bombing: How to Protect Yourself by Watson Davis et al. (1950) into a satirical publication titled Cooking: How to Protect Yourself. The new publication posited cooking as a dangerous act with repercussions akin to those of atomic destruction, from which the only salvation available to humankind is UberEats. The student wrote, "My alteration is meant to show [that] modern people rely heavily on delivery applications and seem to be fearful of cooking [on] their own." His book satirizes technological determinism and solutionism, and seeks to comment on the overuse of food delivery services and the unsustainable environmental and social factors included in reliance on such services, as well as the precarity of the workforce entailed in such services.
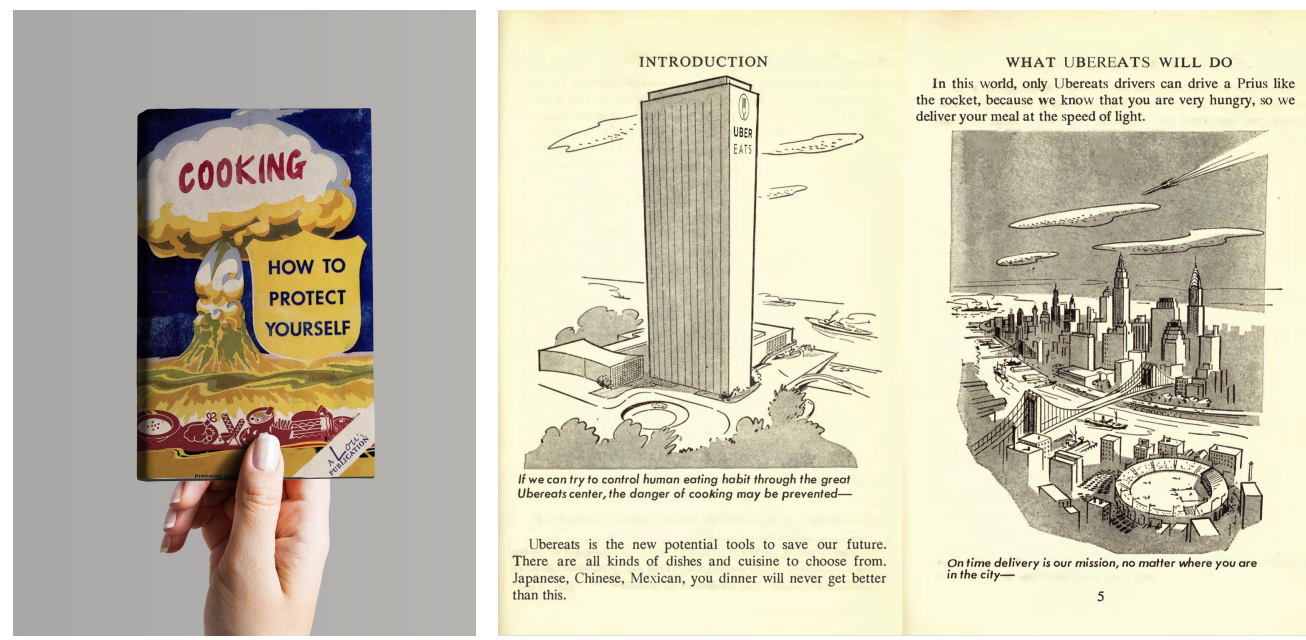
Figures 12 and 13. The cover and an inside spread from the book, Cooking: How to Protect Yourself, produced by student Qiaodan Lou in Copy Culture (2019) as a détournement of the 1950s text, Atomic Bombing: How to Protect Yourself.

Other students used the assignment to comment on social oppressions such as the patriarchy. For instance, after browsing through a collection of TV Guides from the 1950s and 1960s, one student felt overwhelmed by the strict prescriptions of gender roles embodied in the guides' advertisements and titles of show programming. She chose to create a new publication titled, TV Guide: What is TV Doing to Men?, which was a fictitious TV Guide that questioned the roles of media and advertising in reinforcing gender roles. In the détourned version of the TV Guide, “...girls don't cry about figure problems... they just earn money..." like their male counterparts. The student wrote that she "wanted to bring attention and give a voice to women fighting the dominant narrative of the patriarchy" with her new publication.
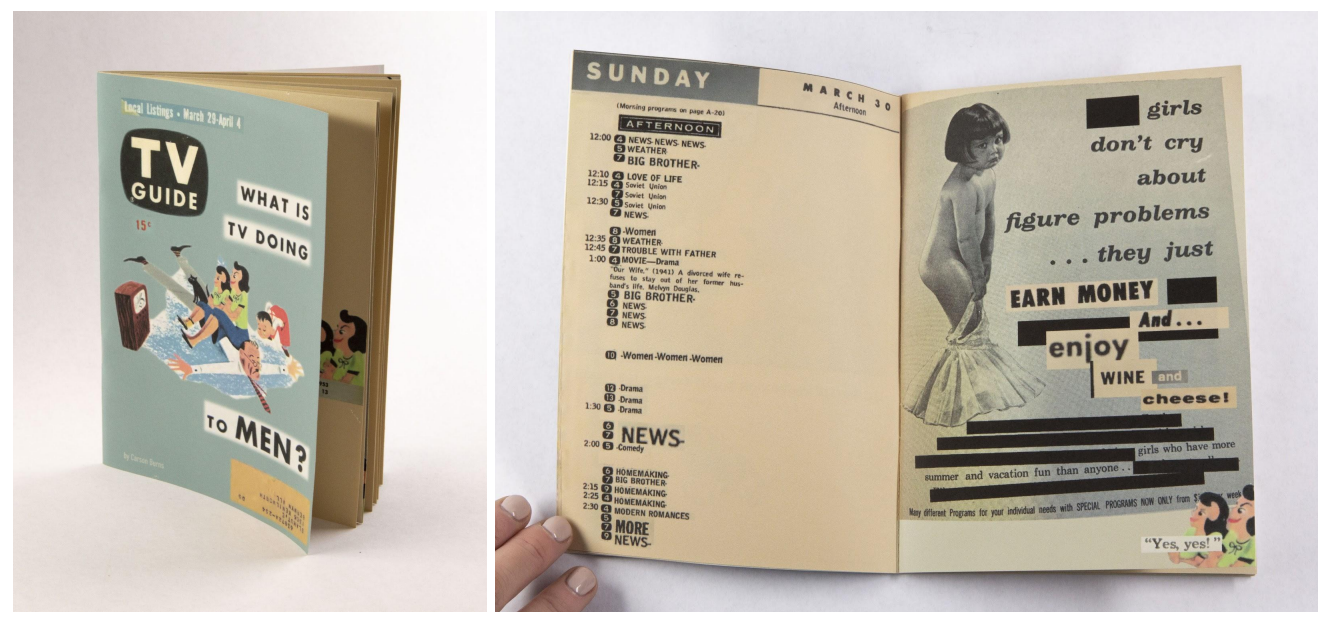

Figures 14 and 15. The cover and an inside spread from the book, TV Guide: What Is TV Doing to Men?, produced by student Carson Burns in Copy Culture (2019) as a détournement of TV Guides from the 1950s and 1960s.

Other students used remix practices to comment on social issues in a way that was personal and less abstract in nature. One détourned the 1943 book, Why Women Cry: or, Wenches with Wrenches by Elizabeth Hawes, into a new 32-page zine of the same title. Her new text explores the emotional landscape created by strictly prescribed gender roles for women in the 1900s and how the patriarchy has shaped the development of gender roles today within her personal life. The student's text begins from the antiquated expectations of gendered labor in the household-cooking, cleaning, ironing, and serving their heterosexual male partners - but then shifts to focus on the student's own mother, who has taken on a similar role in her family. The student's text ends with a quote from the original text which now emanates from her mother-"You will learn from my mistakes"-urging the student and her generation of women to resist the ongoing pressures of the patriarchy in their own domestic spheres. 


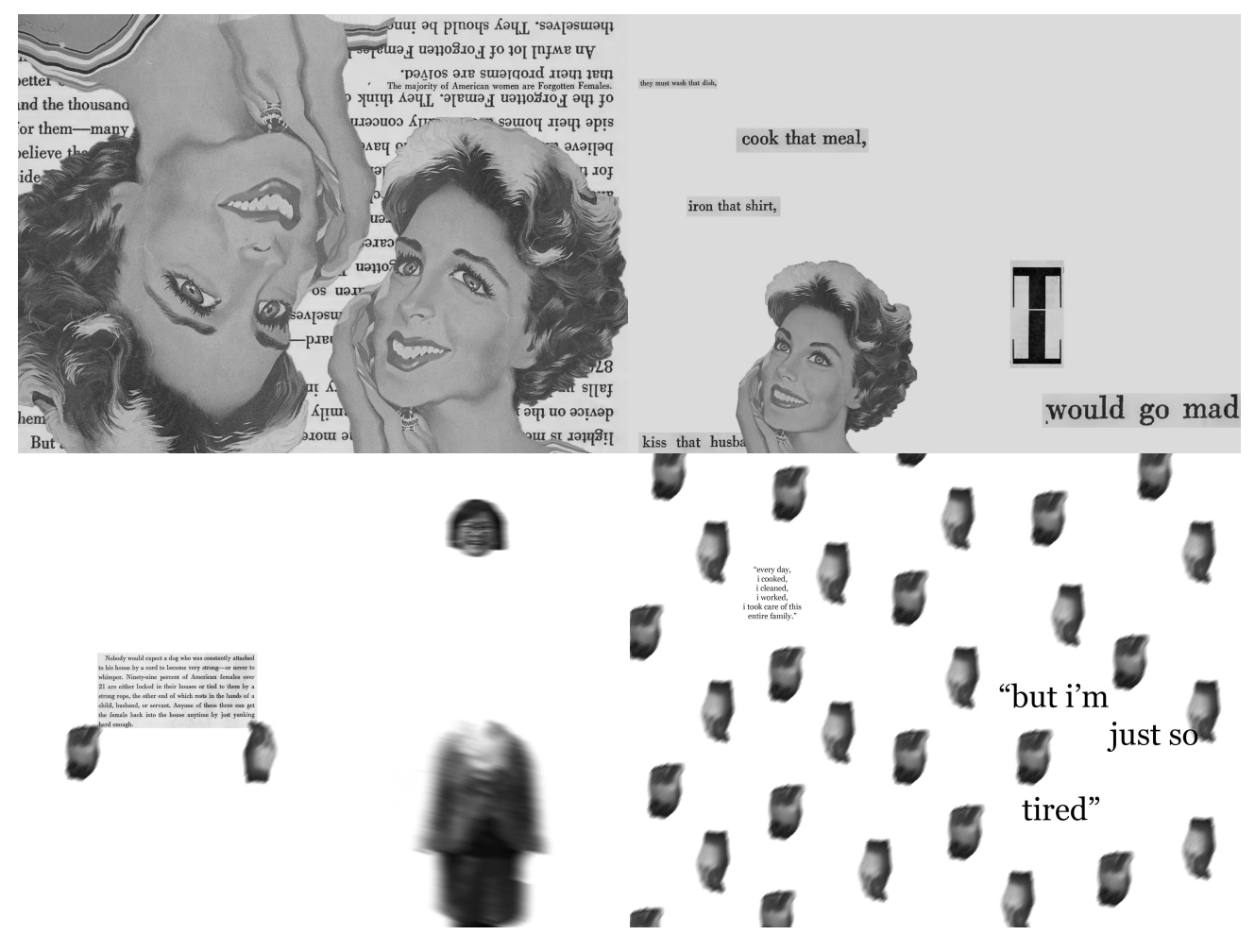

Figures 16, 17, 18, and 19. Inside spreads from the book, Why Women Cry, produced by student Kristie Lang in Copy Culture (2017) as a détournement of the original text Why Women Cry: or, Wenches with Wrenches (1943). The student includes text from the original book, alongside images of 1950s housewives as well as images of her own mother, whose hands float on the pages as they enact the same gendered labor as generations of women who came before her.

It is a risky artistic move to tie one's own family into larger social questions of gender oppression, yet the student who produced Why Women Cry felt comfortable doing so within the context of the remix. In détourning an existing text and reconfiguring original source material, this student finally felt comfortable discussing the politics and configurations of her own family structure. For this student and many others in my course, I have observed that remix practices act almost as one of Brian Eno's "oblique strategies" into difficult subject material: they allow students to produce artistic works of social critiques that might have been previously out of reach.

\section{THE PEDAGOGICAL VALUE OF FAIR USE PRINCIPLES}

A final way that remix pedagogy serves art and design students concerns the ways in which it familiarizes students with the principles of fair use. As intellectual property lawyers teach, fair use is determined by four factors which govern a derivative work's relation to its source material, as well as market factors on a source: (1) the purpose and character of the new work, (2) the nature of the original work, (3) the amount or substantiality of material used, and (4) the effect on the market 
of the original work. ${ }^{34}$ Fair use is often scary to art professionals and students alike because it is always determined by litigation: that is, fair use can be determined only via the legal system. ${ }^{35}$

To address the complications associated with fair use in the visual arts, the College Art Association (CAA), the nation's leading academic art and design organization, tapped Patricia Aufderheide and Peter Jaszi, professors at the American University in the School of Communication and at Washington College of Law's Program on Information Justice and Intellectual Property, respectively, to develop a set of guidelines in fair use for the visual arts. Aufderheide and Jaszi produced CAA's 2015 document, Code of Best Practices in Fair Use for the Visual Arts, to offer visual arts professionals a set of principles for the invocation and implementation of copyrighted materials in writing, teaching, and art production, as well as in museums and digital collections. ${ }^{36}$

The Code of Best Practices in Fair Use for the Visual Arts's section on artistic production, in particular, notes that remixing existing artworks is "part of the construction of new culture, which necessarily builds on existing culture." ${ }^{37}$ It lays out a series of guidelines, including that any remix should be transformative, justified, credited, and cited, unless there are meaningfully articulable aesthetic reasons not to do so. The aim of this section of the code is to equip art practitioners with the legal tools to engage in the free exchange of culture via remix ethics and aesthetics practices with clear guidelines to reduce fear of transgression, as well as to understand how to concretely apply the nuances of fair use's four factors to artistic production.

Just as art professionals benefit from the guidelines laid out by Aufderheide and Jaszi in CAA's Code, so too do art and design students benefit substantially from learning principles of fair use in the classroom. When art and design students learn about fair use, they are able to distinguish it from plagiarism, and they become far more sophisticated in their conceptions of ideation and copying. Moreover, fair use doctrines require complex reasoning, such as understanding what makes a work "transformative" in nature (the first factor), as is almost always the case in works of parody or satire. ${ }^{38}$ Finally, when art and design students learn about the four factors, I have observed that their fear of violating copyright diminishes greatly, and they are able to participate freely in remix culture. This participation enables them to actively engage in the production and reproduction of culture.

Such was the case in one student's final project in Copy Culture, a digital piece titled The Anti Network (figure 20). The Anti Network was a cult-like, online social networking platform dedicated to communally protecting users from what the artist dubbed Facebook's "demonizing" tactics of data sharing, advertisement targeting, and undue influence over the greater state of society. The Anti Network published a series of video art pieces that remixed Facebook advertisements, news clips, and online screen-captures of Facebook usage in an attempt to urge people to delete their Facebook accounts. The organization was rife with cultist overtones and Satanic rhetoric, at once underscoring the "cult" that is Facebook while at the same time persuading users to defect from the 
Facebook cult and join the resistance. The student urged, "It's time the lies, corruption, and manipulation of our public are out of the hands of Mark Zuckerberg."

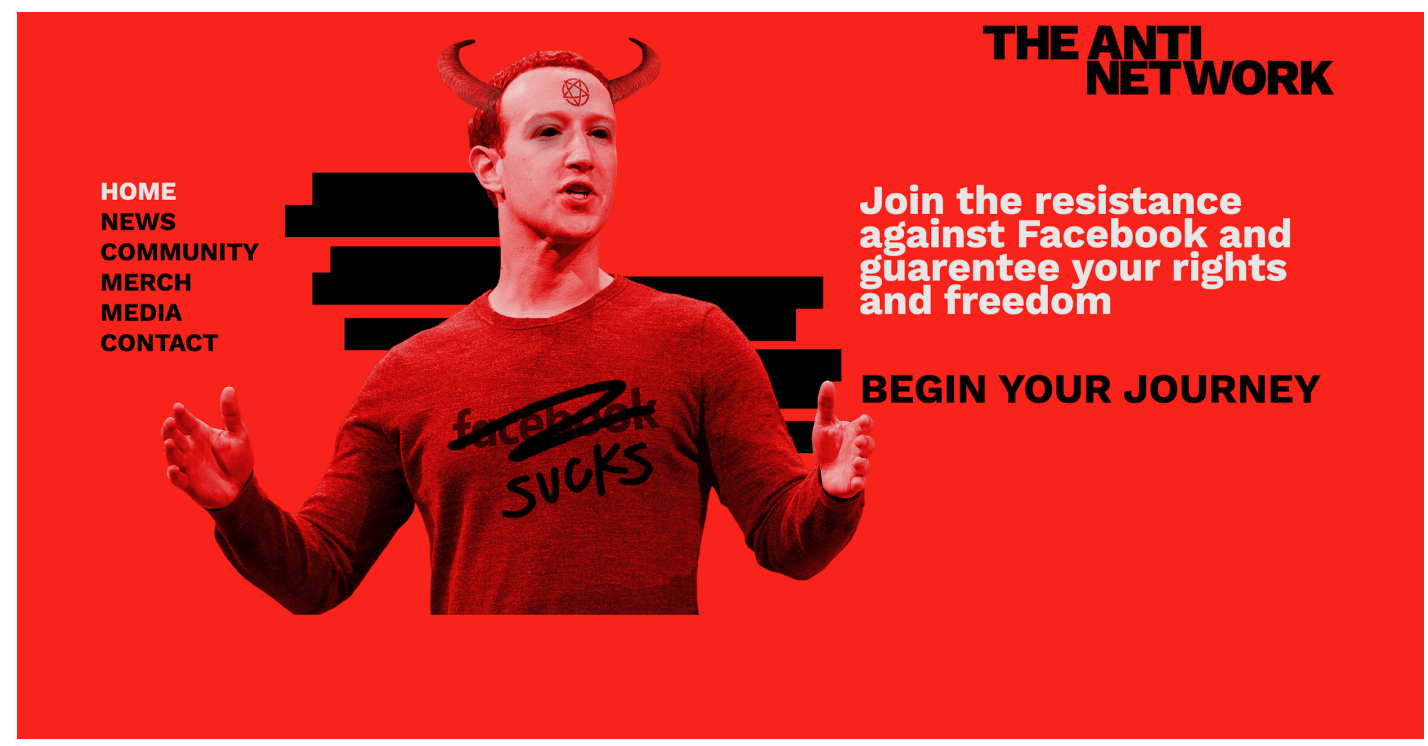

\section{Figure 20. Screenshot of the social networking website titled The Anti Network, created by Copy Culture student Mackenzie Miller (2019) in order to critique Facebook.}

Before learning the four factors of fair use, this student would not have felt comfortable reusing Facebook source material as social critique. Remix pedagogy now allowed this student to actively engage in the reproduction of culture. This student's project reminds us that remix culture, as a whole, is associated with the vibrant tenets of open source culture, which foreground collaboration, sharing, and the democratization of information. If it is true that in our increasingly technologized society, we must either learn to "program" or "be programmed," as Douglas Rushkoff teaches, then remix culture offers us the opportunity to program as agent participants of culture and technology. ${ }^{39}$ Indeed, in the face of increasing software restrictions, licensing fees, and a black-boxed society, remix culture promotes agency not merely for art and design students, but also for artistic disciplines more broadly as they increasingly collide with digital media and the digital landscape. When incorporated into art and design pedagogy, remix tactics help catalyze the personal agency of art students to comment on the sociopolitical and increasingly technological world around them.

\section{CONCLUSION}

In this paper, I have argued that remix pedagogy productively destabilizes archaic notions of authorship, creativity, collaboration, and ownership in artistic practices. In doing so, remix practices offer new modes of creation to art and design students and promote creative production and ideation that, crucially, enable artistic practice to be used as social critique. Indeed, remixed works "succeed when they show others something new," writes Lawrence Lessig, not merely when they rehash their sources. ${ }^{40}$ Lessig continues: 
Like a great essay or a funny joke, a remix draws upon the work of others in order to do new work. It is great writing without words. It is creativity supported by a new technology. ${ }^{41}$

Indeed, as this "new technology" that enables remix culture surrounds us in our daily lives online, the time has come to incorporate it into arts curricula. While art and design students must learn foundations and self-authorship, advanced students can be productively introduced to contemporary remix practices that reconfigure notions of originality and authenticity, and they can leverage fair use to render appropriation as creative practice.

\section{ENDNOTES}

1. Bianconi, Giampaolo. “An Interview with Metahaven,” February 20, 2013. https://rhizome.org/editorial/2013/feb/20/metahaven-interview/.

2. Liu, Chen-Chung, Wei-Chen Chen, Hung-Ming Lin, and Yun-Yin Huang. "A Remix-Oriented Approach to Promoting Student Engagement in a Long-Term Participatory Learning Program." Computers \& Education 110 (July 2017): 1-15. https://doi.org/10.1016/j.compedu.2017.03.002. 3. As a working definition, by "remix" I mean a work that appropriates, uses, and changes existing source material to produce a new creative outcome that is derivative in nature. Or put differently, in an often-cited definition that is not media bound (meaning not chained to any particular medium), to remix is to "take cultural artifacts and combine and manipulate them into new kinds of creative blends" (see Knobel, Michele, and Colin Lankshear. "Remix: The Art and Craft of Endless Hybridization." Journal of Adolescent \& Adult Literacy 52, no. 1 (September 2008): 22-33. https://doi.org/10.1598/JAAL.52.1.3.)

4. For a discussion on the history of the term remix and visual arts entanglements with it, see Eduardo Navas's chapter, "Remix " in Keywords in Remix Studies, eds. Owen Gallagher, xtine burrough, and Eduardo Navas, 246-58. New York: Routledge, 2018.

5. I developed this course in 2017 and teach it on an ongoing basis. Throughout this paper I make my arguments by employing qualitative research, case studies, assignments, and student work from my teaching of Copy Culture at the University of San Francisco.

6. Dubisar, Abby M., Claire Lattimer, Rahemma Mayfield, Makayla McGrew, Joanne Myers, Bethany Russell, and Jessica Thomas. "Haul, Parody, Remix: Mobilizing Feminist Rhetorical Criticism With Video." Computers and Composition 44 (June 2017): 52-66.

https://doi.org/10.1016/j.compcom.2017.03.002; Wargo, Jon. "Hacking Heteronormativity and Remixing Rhymes: Enacting a [Q]ulturally Sustaining Pedagogy in Middle Grades English Language Arts." Voices from the Middle 24, no. 3 (March 2017): 39-43.

7. Kelly, T. Mills. “'But Mine's Better': Teaching History in a Remix Culture on JSTOR.” The History Teacher 44, no. 3 (May 2011): 369-77. https://www.jstor.org/stable/41303990?seq=1. 8. Dubisar, Abby M., and Jason Palmeri. "Palin/Pathos/Peter Griffin: Political Video Remix and Composition Pedagogy." Computers and Composition 27, no. 2 (June 2010): 77-93. https://doi.org/10.1016/j.compcom.2010.03.004.

9. Liu, Chen-Chung, Wei-Chen Chen, Hung-Ming Lin, and Yun-Yin Huang. "A Remix-Oriented Approach to Promoting Student Engagement in a Long-Term Participatory Learning Program." Computers \& Education 110 (July 2017): 1-15. https://doi.org/10.1016/j.compedu.2017.03.002. 
10. Dusenberry, Lisa, Liz Hutter, and Joy Robinson. "Filter. Remix. Make.: Cultivating Adaptability Through Multimodality." Journal of Technical Writing and Communication 45, no. 3 (July 2015): 299-322. https://doi.org/10.1177/0047281615578851.

11. MacDonald, Michael B., eds. Remix and Life Hack in Hip Hop: Towards a Critical Pedagogy of Music. Rotterdam: Sense Publishers, 2016. https://doi.org/10.1007/978-94-6300-500-5.

12. Callahan, Meg, and Jennifer M. King. "Classroom Remix: Patterns of Pedagogy in a TechnoLiteracies Poetry Unit." Journal of Adolescent \& Adult Literacy 55, no. 2 (October 2011): 13444. https://doi.org/10.1002/JAAL.00016; Edwards, Dustin W. "Framing Remix Rhetorically: Toward A Typology of Transformative Work." Computers and Composition 39 (March 2016): 41-54. https://doi.org/10.1016/j.compcom.2015.11.007.; Stedman, Kyle D. "Remix Literacy and Fan Compositions." Computers and Composition 29, no. 2 (June 2012): 107-23. https://doi.org/10.1016/j.compcom.2012.02.002; Yancey, Kathleen Blake. "Re-Designing Graduate Education in Composition and Rhetoric: The Use of Remix as Concept, Material, and Method." Computers and Composition 26, no. 1 (January 2009): 4-12.

https://doi.org/10.1016/j.compcom.2008.11.004; Colton, Jared Sterling. "Revisiting Digital Sampling Rhetorics with an Ethics of Care." Computers and Composition 40 (June 2016): 19-31. https://doi.org/10.1016/j.compcom.2016.03.006; Scanlon, Molly J. "The Work of Comics Collaborations: Considerations of Multimodal Composition for Writing Scholarship and Pedagogy." Composition Studies 43, no. 1 (2015): 105-30.

https://www.jstor.org/stable/43501880.

13. Dubisar, Abby M., Claire Lattimer, Rahemma Mayfield, Makayla McGrew, Joanne Myers, Bethany Russell, and Jessica Thomas. "Haul, Parody, Remix: Mobilizing Feminist Rhetorical Criticism With Video." Computers and Composition 44 (June 2017): 52-66.

https://doi.org/10.1016/j.compcom.2017.03.002; and Dubisar, Abby M., and Jason Palmeri. "Palin/Pathos/Peter Griffin: Political Video Remix and Composition Pedagogy." Computers and Composition 27, no. 2 (June 2010): 77-93. https://doi.org/10.1016/j.compcom.2010.03.004.

14. See burrough, xtine, and Emily Erickson. "Let's Go Crazy: Lenz v. Universal in the New Media Classroom.” Journal of Interactive Technology and Pedagogy 1 (Spring 2012). https://jitp.commons.gc.cuny.edu/lets-go-crazy-lenz-v-universal-in-the-new-media-classroom/. 15. See Dail, Jennifer S., and Nick Thompson. "Talking Back: Remix as a Tool to Help Students Exercise Authority When Making Meaning." The ALAN Review 43, no. 3 (2016);

Hackney, Sean. "Effective Teaching Remix: Answering the Call for Digital Literacy." Hybrid Pedagogy, July 22, 2015. https://hybridpedagogy.org/answering-the-call-for-digital-literacy/; Gainer, Jesse S., and Diane Lapp. "Remixing Old and New Literacies = Motivated Students." The English Journal 100, no. 1 (September 1, 2010): 58-64. https://www.jstor.org/stable/20787692; and Purtee, Melissa. "Engage Your Students from Day One with an Art History Remix." The Art of Education University, August 30, 2017. https://theartofeducation.edu/2017/08/30/get-kidsthinking-creativily-art-history-remix/.

16. Diakopoulos, Nicholas, Kurt Luther, Yevgeniy (Eugene) Medynskiy, and Irfan Essa. "The Evolution of Authorship in a Remix Society." In Proceedings of the 18th Conference on Hypertext and Hypermedia - HT '07, 133. Manchester, UK: ACM Press, 2007. https://doi.org/10.1145/1286240.1286272. Also, see the essays in the "History" section of The Routledge Companion to Remix Studies, edited by Eduardo Navas, Owen Gallagher, and xtine burrough, New York: Routledge, 2015.

17. Navas, Eduardo, Owen Gallagher, and xtine burrough. The Routledge Companion to Remix Studies. New York: Routledge, 2015, 2.

18. Lethem, Jonathan. “The Ecstasy of Influence.” Harper's Magazine, February 2007. https://harpers.org/archive/2007/02/the-ecstasy-of-influence/. 
19. Ibid.

20. Briz, Nick. "Piratical Practices.” Accessed December 4, 2020.

http://piraticalpractices.net/syllabus/.

21. Lethem, Jonathan. “The Ecstasy of Influence.” Harper's Magazine, February 2007.

https://harpers.org/archive/2007/02/the-ecstasy-of-influence/.

22. Rudenstine, Antonia, Sydney Schaef, Dixie Bacallao, and Sarah Hakani. "Meeting Students

Where They Are," 2018. https://files.eric.ed.gov/fulltext/ED590520.pdf.

23. Gladwell, Malcolm. "Creation Myth.” The New Yorker, May 9, 2011.

https://www.newyorker.com/magazine/2011/05/16/creation-myth.

24. Brilliant, Richard. "Roman Copies: Degrees of Authenticity." Source: Notes in the History of Art 24, no. 2 (2005): 19-27. https://www.jstor.org/stable/23208110.

25. Barthes, Roland. "The Death of the Author." In Image, Music, Text, translated by S. Heath, 142-48. New York: Hill and Wang, 1977.

https://sites.tufts.edu/english292b/files/2012/01/Barthes-The-Death-of-the-Author.pdf.

26. Foucault, Michel. "What Is an Author?" In Language, Counter-Memory, Practice: Selected

Essays and Interviews, edited by Donald F. Bouchard, 113-38. Ithaca: Cornell University Press, 1977.

27. Lethem, Jonathan. “The Ecstasy of Influence.” Harper's Magazine, February 2007.

https://harpers.org/archive/2007/02/the-ecstasy-of-influence/.

28. Artists and artworks included were: Kenneth Goldsmith's Uncreative Writing (creative writing); Sherrie Levine's After Walker Evans, Richard Prince's Cowboys and New Portraits, Michael Mandiberg's AfterSherrieLevine, and Penelope Umbrico's Suns (photography); Elaine Sturtevant's Warhol Licorice Marilyn and Kehinde Wiley Napoleon's Leading the Army Over the Alps (painting); Craig Baldwin's Sonic Outlaws, Michelle Ellsworth's The Burger Foundation and tifprabap.org, Kutiman's ThruYou, Oliver Laric's Versions, Paul Pfeiffer's The Long Count, DJ Spooky's Sinfonia Antarctica, and Ryan Trecartin's River of the Net (video and performance); Barbie Liberation Organization, and The Yes Men's Hijinks such as The New York Times Special Edition and Dow Does The Right Thing (culture jamming); Aram Bartholl's Dropping the

Internet and Forgot your Password?, Michael Mandiberg's Postmodern Times, Antonio

Roberts's Permission Taken, and Ubermorgen's anti-capitalist initiatives, Google Will Eat Itself and Amazon Noir (new media).

29. Pecha Kucha ("chit chat" in Japanese) is a visual presentation format with timed slides that auto-advance every twenty seconds. It originated in Tokyo in 2003, and has been widely adopted as a dynamic method to produce time-constrained presentations.

30. Quoted in Goldsmith, Kenneth. "I Look to Theory Only When I Realize That Somebody Has Dedicated Their Entire Life to a Question I Have Only Fleetingly Considered.” Poetry Magazine. Poetry Magazine, April 2015.

https://www.poetryfoundation.org/poetrymagazine/articles/70209/i-look-to-theory-only-when-irealize-that-somebody-has-dedicated-their-entire-life-to-a-question-i-have-only-fleetinglyconsidered.

31. FICTILIS. “10.-22.-38 Astoria.” Accessed December 4, 2020.

http://www.fictilis.com/project/10-22-38-astoria.

32. Lessig, Lawrence. Remix: Making Art and Commerce Thrive in the Hybrid Economy. New York: Penguin Books, 2009.

33. Guy Debord, and Gil J. Wolman, “A User's Guide to Détournement," trans., Ken Knabb. Les Lèvres Nues, May 1956. https://www.cddc.vt.edu/sionline/presitu/usersguide.html. 
34. Stim, Rich. "Measuring Fair Use: The Four Factors - Copyright Overview." Stanford Copyright and Fair Use Center. Accessed December 4, 2020.

https://fairuse.stanford.edu/overview/fair-use/four-factors/.

35. The principles of fair use can of course be analyzed outside of litigation, but cannot be definitively and finally determined without litigation. Analysis has produced many important disciplinary tools (see Aufderheide, Patricia, and Peter Jaszi. "Code of Best Practices in Fair Use for the Visual Arts." n.p.: College Art Association, 2015. https://cmsimpact.org/wp-

content/uploads/2016/01/best practice rfnl.pdf) and pedagogical tools (see burrough, xtine, and Emily Erickson. "Let's Go Crazy: Lenz v. Universal in the New Media Classroom." Journal of Interactive Technology and Pedagogy 1 [Spring 2012)]). https://jitp.commons.gc.cuny.edu/letsgo-crazy-lenz-v-universal-in-the-new-media-classroom/.

36. Aufderheide, Patricia, and Peter Jaszi. "Code of Best Practices in Fair Use for the Visual Arts.” n.p.: College Art Association, 2015. https://cmsimpact.org/wpcontent/uploads/2016/01/best practice rfnl.pdf.

37. Ibid, 11.

38. For an important analysis on teaching fair use to students from both studio art and legal disciplines, see burrough, xtine, and Emily Erickson. "Let's Go Crazy: Lenz v. Universal in the New Media Classroom.” Journal of Interactive Technology and Pedagogy 1 (Spring 2012). https://jitp.commons.gc.cuny.edu/lets-go-crazy-lenz-v-universal-in-the-new-media-classroom/. 39. Rushkoff, Douglas. Program or Be Programmed: Ten Commands for a Digital Age.

Berkeley, CA: Soft Skull Press, 2011.

40. Lessig, Lawrence. Remix: Making Art and Commerce Thrive in the Hybrid Economy. New York: Penguin Books, 2009, 82.

41. Ibid.

\section{REFERENCES}

Aufderheide, Patricia, and Peter Jaszi. "Code of Best Practices in Fair Use for the Visual Arts." n.p.: College Art Association, 2015. https://cmsimpact.org/wpcontent/uploads/2016/01/best practice rfnl.pdf.

Barthes, Roland. "The Death of the Author." In Image, Music, Text. Translated by S. Heath, 14248. New York: Hill and Wang, 1977. https://sites.tufts.edu/english292b/files/2012/01/Barthes-The-Death-of-the-Author.pdf.

Bianconi, Giampaolo. “An Interview with Metahaven,” February 20, 2013. https://rhizome.org/editorial/2013/feb/20/metahaven-interview/.

Brilliant, Richard. "Roman Copies: Degrees of Authenticity." Source: Notes in the History of Art 24, no. 2 (2005): 19-27. https://www.jstor.org/stable/23208110.

Briz, Nick. "Piratical Practices.” Accessed December 4, 2020. http://piraticalpractices.net/syllabus/.

burrough, xtine, and Emily Erickson. "Let's Go Crazy: Lenz v. Universal in the New Media Classroom." Journal of Interactive Technology and Pedagogy 1 (Spring 2012). https://jitp.commons.gc.cuny.edu/lets-go-crazy-lenz-v-universal-in-the-new-mediaclassroom/. 
Callahan, Meg, and Jennifer M. King. "Classroom Remix: Patterns of Pedagogy in a TechnoLiteracies Poetry Unit.” Journal of Adolescent \& Adult Literacy 55, no. 2 (October 2011): 134-44. https://doi.org/10.1002/JAAL.00016.

Colton, Jared Sterling. "Revisiting Digital Sampling Rhetorics with an Ethics of Care." Computers and Composition 40 (June 2016): 19-31. https://doi.org/10.1016/j.compcom.2016.03.006.

Dail, Jennifer S., and Nick Thompson. "Talking Back: Remix as a Tool to Help Students Exercise Authority When Making Meaning." The ALAN Review 43, no. 3 (2016).

Debord, Guy, and Gil J. Wolman. “A User's Guide to Détournement.” Translated by Ken Knabb. Les Lèvres Nues, May 1956. https://www.cddc.vt.edu/sionline/presitu/usersguide.html.

Diakopoulos, Nicholas, Kurt Luther, Yevgeniy (Eugene) Medynskiy, and Irfan Essa. "The Evolution of Authorship in a Remix Society." In Proceedings of the 18th Conference on Hypertext and Hypermedia - HT '07, 133. Manchester, UK: ACM Press, 2007. https://doi.org/10.1145/1286240.1286272.

Dubisar, Abby M., Claire Lattimer, Rahemma Mayfield, Makayla McGrew, Joanne Myers, Bethany Russell, and Jessica Thomas. "Haul, Parody, Remix: Mobilizing Feminist Rhetorical Criticism With Video." Computers and Composition 44 (June 2017): 52-66. https://doi.org/10.1016/j.compcom.2017.03.002.

Dubisar, Abby M., and Jason Palmeri. "Palin/Pathos/Peter Griffin: Political Video Remix and Composition Pedagogy." Computers and Composition 27, no. 2 (June 2010): 77-93. https://doi.org/10.1016/j.compcom.2010.03.004.

Dusenberry, Lisa, Liz Hutter, and Joy Robinson. "Filter. Remix. Make.: Cultivating Adaptability Through Multimodality." Journal of Technical Writing and Communication 45, no. 3 (July 2015): 299-322. https://doi.org/10.1177/0047281615578851.

Edwards, Dustin W. "Framing Remix Rhetorically: Toward a Typology of Transformative Work." Computers and Composition 39 (March 2016): 41-54. https://doi.org/10.1016/j.compcom.2015.11.007.

FICTILIS. “10.-22.-38 Astoria.” Accessed December 4, 2020. http://www.fictilis.com/project/1022-38-astoria.

Foucault, Michel. "What Is an Author?” In Language, Counter-Memory, Practice: Selected Essays and Interviews, edited by Donald F. Bouchard, 113-38. Ithaca: Cornell University Press, 1977.

Gainer, Jesse S., and Diane Lapp. "Remixing Old and New Literacies = Motivated Students." The English Journal 100, no. 1 (September 1, 2010): 58-64. https://www.jstor.org/stable/20787692.

Gladwell, Malcolm. “Creation Myth.” The New Yorker, May 9, 2011. https://www.newyorker.com/magazine/2011/05/16/creation-myth. 
Goldsmith, Kenneth. "I Look to Theory Only When I Realize That Somebody Has Dedicated Their Entire Life to a Question I Have Only Fleetingly Considered." Poetry Magazine, April 2015. https://www.poetryfoundation.org/poetrymagazine/articles/70209/i-look-totheory-only-when-i-realize-that-somebody-has-dedicated-their-entire-life-to-a-question-ihave-only-fleetingly-considered.

Hackney, Sean. "Effective Teaching Remix: Answering the Call for Digital Literacy." Hybrid Pedagogy, July 22, 2015. https://hybridpedagogy.org/answering-the-call-for-digitalliteracy/.

Kelly, T. Mills. “'But Mine's Better': Teaching History in a Remix Culture on JSTOR.” The History Teacher 44, no. 3 (May 2011): 369-77. https://www.jstor.org/stable/41303990?seq=1.

Knobel, Michele, and Colin Lankshear. "Remix: The Art and Craft of Endless Hybridization." Journal of Adolescent \& Adult Literacy 52, no. 1 (September 2008): 22-33. https://doi.org/10.1598/JAAL.52.1.3.

Lessig, Lawrence. Remix: Making Art and Commerce Thrive in the Hybrid Economy. New York: Penguin Books, 2009.

Lethem, Jonathan. “The Ecstasy of Influence.” Harper's Magazine, February 2007. https://harpers.org/archive/2007/02/the-ecstasy-of-influence/.

Liu, Chen-Chung, Wei-Chen Chen, Hung-Ming Lin, and Yun-Yin Huang. "A Remix-Oriented Approach to Promoting Student Engagement in a Long-Term Participatory Learning Program." Computers \& Education 110 (July 2017): 1-15. https://doi.org/10.1016/j.compedu.2017.03.002.

MacDonald, Michael B., ed. Remix and Life Hack in Hip Hop: Towards a Critical Pedagogy of Music. Rotterdam: Sense Publishers, 2016. https://doi.org/10.1007/978-94-6300-500-5.

Navas, Eduardo. "Remix." In Keywords in Remix Studies, edited by Owen Gallagher, xtine burrough, and Eduardo Navas, 246-58. New York: Routledge, 2018.

Navas, Eduardo, Owen Gallagher, and xtine burrough. The Routledge Companion to Remix Studies. New York: Routledge, 2015.

Purtee, Melissa. "Engage Your Students from Day One with an Art History Remix." The Art of Education University, August 30, 2017. https://theartofeducation.edu/2017/08/30/getkids-thinking-creativily-art-history-remix/.

Rudenstine, Antonia, Sydney Schaef, Dixie Bacallao, and Sarah Hakani. "Meeting Students Where They Are," 2018. https://files.eric.ed.gov/fulltext/ED590520.pdf.

Rushkoff, Douglas. Program or Be Programmed: Ten Commands for a Digital Age. Berkeley, CA: Soft Skull Press, 2011. 
Scanlon, Molly J. "The Work of Comics Collaborations: Considerations of Multimodal Composition for Writing Scholarship and Pedagogy." Composition Studies 43, no. 1 (2015): 105-30. https://www.jstor.org/stable/43501880.

Stedman, Kyle D. "Remix Literacy and Fan Compositions." Computers and Composition 29, no. 2 (June 2012): 107-23. https://doi.org/10.1016/j.compcom.2012.02.002.

Stim, Rich. "Measuring Fair Use: The Four Factors - Copyright Overview." Stanford Copyright and Fair Use Center. Accessed December 4, 2020.

https://fairuse.stanford.edu/overview/fair-use/four-factors/.

Wargo, Jon. "Hacking Heteronormativity and Remixing Rhymes: Enacting a [Q]ulturally Sustaining Pedagogy in Middle Grades English Language Arts." Voices from the Middle 24, no. 3 (March 2017): 39-43.

Yancey, Kathleen Blake. "Re-Designing Graduate Education in Composition and Rhetoric: The Use of Remix as Concept, Material, and Method." Computers and Composition 26, no. 1 (January 2009): 4-12. https://doi.org/10.1016/j.compcom.2008.11.004.

\section{AUTHOR BIO}

Liat Berdugo is an artist and writer whose work investigates embodiment, labor, and militarization in relation to capitalism, technological utopianism, and the Middle East. Her work has been exhibited and screened at Yerba Buena Center for the Arts (San Francisco), MoMA PS1 (New York), Transmediale (Berlin), V2_Lab for the Unstable Media (Rotterdam), and The Wrong Biennale (online), among others. Her writing appears in Rhizome, Temporary Art Review, Real Life, Places, and The Institute for Network Cultures, among others, and her latest book, The Weaponized Camera in the Middle East, is forthcoming from Bloomsbury in 2021. She is one half of the art collective, Anxious to Make, and is the co-founder and co-curator of the Living Room Light Exchange, a monthly new media art series. Berdugo received an MFA from RISD and a BA from Brown University. She is currently an assistant professor of Art + Architecture at the University of San Francisco. Berdugo lives and works in Oakland, CA. 